\title{
Too much of a good thing? Best interests of the child in South African jurisprudence
}

\section{Ann Skelton}

\begin{abstract}
SUMMARY
The South African Constitutional Court is often lauded for its application of best interests in its judgments. This article acknowledges the positive aspects of the Court's approach, especially in the earlier cases, but also poses a question - does the Court go too far in applying best interests, in situations where an equally or more appropriate right in the Bill of Rights is available - or where a right can be more fully interpreted through recourse to international law? Two recent cases are analysed to demonstrate the concern. It is argued that the most rights-based approach is achieved with the Court pronounces on a clear rights violation, either in the Constitution or the Convention, and then use best interests to either weigh rights, justify a derogation of a right, to fill in any normative gaps where a particular right is not clearly enunciated in the Constitution or international law, or where it is necessary to show that the impact of an impugned provision would impact on children more heavily than on adults. It is concluded that the flexibility of best interests is useful, but it should not be used so ubiquitously that it prevents normative development of children's rights.
\end{abstract}

\section{Introduction}

This article contains a constructive critique of the South African the Constitutional Court's love affair with the best interests principle. As a practitioner, I have often urged the court to apply best interests in a range of matters, and yet in this contribution I am posing the question - is it possible that resort to best interests can be too much of a good thing? The article traces the origins and development of best interests, and analyses several important cases of the Constitutional Court, citing profound and poetic passages of judgments from the Court on best interests. Being charmed by these, the reader may wonder - what's the problem?

Briefly stated, my concern is as follows: While I am deeply appreciative that the Constitutional Court has developed a strong best interests jurisprudence, I will analyse some examples where the Court could just as easily - perhaps more correctly - have based its decision on another substantive right in chapter 2 of the Constitution, ${ }^{1}$ or a more substantive right in the Convention on the Rights of the Child. I will observe that the Court risks spreading the right too thinly, an approach which Sachs J warned against in $S v M$ (Centre for Child Law as Amicus Curiae). ${ }^{2}$ I argue that what is needed is a rights based approach - viewing children as the bearers of all rights in the Constitution.

1 The Bill of Rights is contained in chapter 2 of the Constitution (Constitution of South Africa Act 105 of 1996).

22008 (3) SA 232 (CC).

How to cite: Skelton 'Too much of a good thing? Best interests of the child in South African jurisprudence' 2019 De Jure Law Journal 557-579

http://dx.doi.org/10.17159/2225-7160/2019/v52a32 
In General Comment No 14 on the right of the child to have his or her best interest taken as a primary consideration (2013), ${ }^{3}$ the Committee on the Rights of the Child reminded States Parties that there is no hierarchy of rights in the Convention and that "an adult's judgment of a child's best interests cannot override the obligation to respect all the child's rights under the Convention". 4 The selection of cases discussed here show that the South African Constitutional Court has usually found violations of specific rights, with best interests being invoked alongside these ${ }^{5}$ to bolster the decision on the main rights violations, or to cover specific concerns that do not fit neatly under other rights. However, two cases are singled out for attention that show signs of a deviation from that approach.

\section{From origin to inclusion in the Constitution}

The best interests principle was established in South African law through case law in the early 1900 s, $^{6}$ and it developed through case law, particularly in family law and in welfare proceedings. It did not reach the level of being a right until its inclusion in the Bill of Rights in the Constitution. Prior to that it was a principle that was applied, primarily in deciding custody disputes.

The process of transition from the end of the apartheid era in South Africa included the drafting of an Interim Constitution, containing a Bill of Rights. This became law in 1993 (before the first democratic elections) and remained in placed while an elected Constitutional Assembly in Parliament drew up a permanent Constitution. This Interim Constitution did include best interests as a paramount consideration. In the final 1996 Constitution, the best interests clause stands on its own in section 28(2): "A child's best interests are of paramount importance in every matter concerning the child". The word paramount is emphatic - considering that the Convention on the Rights of the Child provides only that a child's best interest shall be a primary consideration. ${ }^{7}$ The African Charter on the Rights and Welfare of the Child ${ }^{8}$ has a slightly higher standard of "the

$3 \mathrm{CRC} / \mathrm{C} / \mathrm{GC} / 14$

4 The Committee was quoting from its earlier General Comment No.13 on the right to protection from all forms of violence, para 61.

5 See, however, Julia Sloth-Nielsen and Benyam D Mezmur," $2+2=5$ ? Exploring the Domestication of the $C R C$ in South African Jurisprudence (2002-2006)" (2008) International Journal of Children's Rights. I agree with Sloth Nielsen and Mezmur's view that in the early cases brought before the Constitutional Court "the main beneficiaries of child rights related cases were in fact adult litigants, who has sought to bolster their claims via children's rights-based arguments". The focus in this article on the post 2000 judgments.

6 Mills has provided a succinct summary of the case law in Mills "Failing children: The Courts' disregard of the best interests of the child in Le Roux $v$ Dey (2014) 131 South African Law Journal 847. The cases she mentions are Cronje v Cronje 1907 TS 871; Tabb v Tabb 1909 TS 1033; Ramsay v Ramsay 1935 SR 84; Mathews v Haswari 1937 WLD 110; Christian v Christian 1945 TPD; Fletcher $v$ Fletcher 1948 (1) SA 130 (A). 
primary consideration". Paramount suggests a yet higher standard, and according to section 28(2), it is to be considered in all matters concerning the child.

The best interests clause in the section 28(2) of the Final Constitution forms part of the children's rights section in the Constitution which deals with a range of children's rights, including the child's right to a name and nationality, to family care or parental care or alternative care if removed from the family environment, immediate access to certain socio economic rights, the right to be protected from abuse and degradation, and from child labour and involvement in armed conflict. There are specific provisions protecting children in the criminal justice system and a right to separate legal representation in civil matters. Of course, beyond section 28 - the children's rights clause - all the other rights in the Constitution apply to children unless they are excluded because such rights only apply to adults, such as the right to vote.

\section{The development of best interests under the Convention on the Rights of the Child}

As the South African Constitution was influenced by the Convention on the Rights of the Child (CRC or the Convention), ${ }^{9}$ it is important to consider how the concept of best interests has developed in international law. Nigel Cantwell, who was deeply involved with the drafting of the Convention, has argued that the drafting history of the Convention shows that the implications of generalising best interests as a primary consideration in all matters concerning the child were not "thought through". ${ }^{10}$ It was the first CRC Committee that decided to elevate the best interests of the child to one of the four "general principles of the Convention", which they did in the context of drafting a list of issues for state reporting. ${ }^{11}$ Despite the fact that the first and subsequent committees clearly viewed best interests as pivotally important, Cantwell points out that it took twenty years before General Comment No.14 on the right of the child to have his or her best interest taken as a primary consideration $(2013)^{12}$ was issued.

7 CRC Article 3(1). However, Art 21 of the Convention requires best interests to be treated as the paramount consideration in the context of adoption.

8 ACRWC Article 4.

9 A Skelton and $\mathrm{P}$ Proudlock "Interpretation, objects, application and implementation of the Act" in CJ Davel and AM Skelton Commentary on the Children's Act 2nd edition 2013-01-11.

10 N Cantwell "Are 'best interests' a pillar or a problem?" in Liefaard and SlothNielsen (eds) The United Nations Convention on the Rights of the Child: Taking stock after 25 years and looking ahead (2017) 61-72.

11 K Hanson and L Lundy "Does exactly what is says on the tin? A critical analysis and alternative conceptualisation of the so-called 'general principles' of the Convention on the Rights of the Child" (2017) 25 (2) International Journal of Children's Rights 285-306.

$12 \mathrm{CRC} / \mathrm{C} / \mathrm{GC} / 14$. 
General Comment 14 did articulate quite neatly how best interest should be viewed as a threefold concept: First, as a substantive right, namely the child's right to have his or her best interests considered. Secondly as an interpretive principle, to be applied in determining whether a legal provision is the most favourable for a child or children. Third, as a rule of procedure, requiring that decision-making processes about a child or a group of children must include a consideration of the impact of the decision on them. ${ }^{13}$

Cantwell takes issue with the fact that the Committee in General Comment 14 followed an "orthodox" approach, accepting the best interests principle, rather than really examining its proper role. He is concerned that because best interests is basically "paternalistic and charitable" it may be dangerous in a Convention that aims to ensure children's human rights. Adults do not have to receive their rights through the prism of best interests, so why should children, he asks. John Tobin, on the other hand, supports the idea of best interests playing a supporting role in children's rights. ${ }^{14}$ He points out that children's rights are not based on a will theory of rights, which would emphasise a child's capacity for making rational choices as a prerequisite for their rights enjoyment, but rather an interests theory of rights, which "are intended to have nexus with their children's best interests". He goes on to explain that this approach will not prevent the child from gaining autonomy in the exercise of their rights as they grow older. ${ }^{15}$

However, Cantwell's concern is about something different. It is about ensuring that children are the bearers of all rights to which they are entitled. He points out that the concept of best interests was developed in an era when children were not recognised as having human rights. In his view there was inadequate debate during drafting of $\mathrm{CRC}$, as to whether the inclusion (and expansion) of the concept was appropriate in a Convention that gave children rights. Cantwell is concerned that the "quasi-obligatory references to 'best interests' can actually impede awareness-raising about the fact that children have human rights as opposed to 'special children's rights'”. ${ }^{16}$ Best interests become a problem when the concept is invoked pointlessly, that is, when reference to a right would or should suffice. He is calling for an approach that sees children's rights promoted and defended on the same basis as the human rights of adults, "for whom 'best interests' are simply not

$13 \mathrm{CRC/C/GC/14,} \mathrm{par} 6$.

14 J Tobin "Judging the judges: Are they adopting the right approach in matters involving children?" (2009) 33(2) Melbourne University Law Review 579.

15 Writing shortly after the Convention was adopted, Eekelaar described this as "dynamic self-determinism". See J Eekelaar "The interests of the child and the child's wishes: The role of self-determinism" (1994) 8 International Journal of Law, Policy and Family 42-6. See further Freeman, writing while the Convention was in development, who developed a typology which he called "liberal paternalism", see M Freeman The rights and wrongs of children (1983).

16 Cantwell (2017) 65. 
regarded as pertinent". ${ }^{17}$ In my view, this may have been what the CRC Committee was driving at in General Comment 14, when the point was made that there is no hierarchy of rights, and that adults'- determination of best interests cannot override the obligation to respect all of the rights in the Convention. ${ }^{18}$

Nevertheless, Cantwell recognises that "in certain well-defined circumstances the spirit embodied in best interests can be useful for reaching decisions involving children, whether individually or a group". 19 Cantwell suggests that "best interests can be useful in filling a gap - or gaps - in rights provisions rather than underpinning the assurance of the human rights of all children." 20 He has outlined a number of situations in which it is legitimate to apply situations. ${ }^{21}$ I have grouped them into three groups. The first group relates to "weighing" either choosing between two or more potential solutions (all of which should be consistent with the human rights of children), or balancing two or more competing human rights. ${ }^{22}$ Also in the weighing group are situations where the rights of others may dominate, for example in custody disputes. The second group relates to a justified derogation from specific rights where this is foreseen by the CRC as being in children's best interests. These are separating children from families, denying contact with parents, envisaging detention of children with adults, excluding parents from judicial proceedings. Another instance that can be grouped with these relates to situations where a temporary decision can be made in emergency situations on the immediate best interests, but subject to a proper assessment of rights at a later date. The third group relates to "broaching issues not covered by existing rights", which he elsewhere describes as "filling gaps". ${ }^{23}$ Similar observations have been made by South African author, Meda Couzens

Cantwell asserts that under the Convention, best interests must always be considered within a broader framework of human rights. Meda Couzens has expressed concern that the South African Constitutional Court relies too easily on sections 28(2) capitalizing on "the permissiveness" of the text, and she observes that the Court sometimes fails to construct its reasoning on the more structured requirements of relevant section $28(1)$ provisions. $^{24}$ This article examines the

17 Cantwell (2017) 65.

$18 \mathrm{CRC} / \mathrm{C} / \mathrm{GC} / 14$, par 4

19 Cantwell (2017) 61-65.

20 Cantwell (2017) 69. Meda Couzens has observed a similar use of best interests as a "gap filler" by the South African Courts, see M Couzens "The best interests of the child and the Constitutional Court: A critical appraisal" (2019) Constitutional Court Review (Forthcoming).

21 Cantwell (2017) 70.

22 In South African Constitutional cases, the Court uses the best interests to establish the scope and potential limitations of other constitutional rights, as well as a right in itself, see further A Friedman, A Pantazis and A Skelton "Children's Rights" (2nd ed, 2013 1: 07-09), in S. Woolman and M. Bishop, Constitutional Law of South Africa (2nd ed.) 40-47.

23 Cantwell (2017) 69. 
jurisprudence of the South African Constitutional Court in the light of this search for a human rights compliant approach to best interests.

\section{Development of a best interests jurisprudence in South Africa}

The very first case of the Constitutional Court dealing with children's rights was $S v$ Williams. ${ }^{25}$ This case abolished whipping as a sentence. The court was asked by counsel to consider children's best interests in addition to other rights violations, but the court based its decision on a violation of "cruel, inhuman and degrading treatment" 26 - correctly, in my view. A few years later, the Court had to consider corporal punishment in private religious schools, in Christian Education South Africa $v$ Minister of Education. ${ }^{27}$ In deciding that the legal ban on corporal punishment was a reasonable and justifiable limitation on the parents' right to religious freedom, the court considered best interests, but again focused on children's right to dignity ${ }^{28}$ and to freedom and security of the person. ${ }^{29}$ In these early cases, we see the Court applying the other rights in the Constitution, and interestingly, the rights focussed on by the Court are rights that are not included in section 28 (the children's rights clause) but elsewhere in the Bill of Rights, showing that, from the outset, the Court applied all the rights in the Bill of Rights to children.

The case of Minister of Welfare and Population Development $v$ Fitzpatrick ${ }^{30}$ was about adoption, an area in which one would expect to see best interests dominate, because it is the only article in the Convention that states that best interests is the paramount consideration. ${ }^{31}$ The Constitutional Court declared a section of the Child Care Act of 1983 invalid because it prevented foreign persons from being able to adopt a child. ${ }^{32}$ The Constitutional Court found that section 28(1), which lists a set of children's rights from name to nationality, through to

24 M Couzens "The Constitutional Court consolidates its child-focused jurisprudence: The case of $C v$ Department of Health and Social Development, Gauteng" 2013 (130) South African Law Journal 672; M Couzens "Le Roux and Others $v$ Dey (Freedom of Expression Institute and Restorative Justice Centre as Amici Curiae) and Children's Rights Approaches to Judging" 2018(21) Potchefstroom Electronic Law Journal.

$25 S v$ Williams and Others 1995 (3) SA 632 (CC)

26 Section 11(2) of the interim Constitution.

27 Christian Education South Africa v Minister of Education 2000 (4) SA 757 (CC), hereafter Christian Education.

28 Section 10 of the Constitution (1996).

29 Section 12 of the Constitution (1996).

30 Minister of Welfare and Population Development $v$ Fitzpatrick and Others 2000 (3) SA 422 (CC), hereafter Fitzpatrick.

31 Article 21 of the CRC (1989).

$32 \mathrm{Mr}$ and Mrs Fitzpatrick were British citizens domiciled in South Africa, with whom the child in question had been living in foster care. Subsequently, the Children's Act 38 of 2005 repealed the whole of the Child Care Act and provided a comprehensive legal framework for adoption and intercountry adoption. 
legal representation in civil proceedings, is not exhaustive of children's rights. The Court found that:

"Section 28(2) requires that a child's best interests have paramount importance in every matter concerning the child. The plain meaning of the words clearly indicates that the reach of s 28(2) cannot be limited to the rights enumerated in s 28(1) and 28(2) must be interpreted to extend beyond those provisions. It creates a right that is independent of those specified in s 28(1)."33

This made it clear that the best interests clause in section 28(2) does not only find application in relation to the rights enumerated in section 28(1), but to all other rights. Importantly, it also clarified that section 28(2) is a right in and of itself, and not merely a guiding principle. In addition to being a self-standing right, it also strengthens other rights. Although this approach could be deduced from the Court's earlier cases of $S v$ Williams and Christian Education, it was positive that the Court set this out clearly so as to guide other courts in this regard.

The case of De Reuck $v$ Director of Public Prosecutions ${ }^{34}$ gave the opportunity for the Constitutional Court to consider the paramountcy of children's rights in a context where it was pitted against another right in the Bill of Rights. This is part of the South African Constitutional approach to limitations. Put briefly, the court may find that a particular law on conduct, on the face of it, infringes a particular right. However, as all rights may be limited, the limitations analysis must weigh other competing rights and interests to determine whether the infringement is reasonable and justifiable. The Court applies best interests as a weighting factor in the limitations analysis. De Reuck was an adult man facing charges for being in possession of materials that fell within the definition of "child pornography". He argued that his right to freedom of expression was infringed by the law relating to the possession of child pornography, and asked that it be found unconstitutional. The High Court from which this appeal case derived had applied a strong children's best interests approach and found that the law prohibiting possession of such material was compatible with the Constitution because of the paramountcy of children's best interests. ${ }^{35}$ However, when the case reached the Constitutional Court, it took a different approach. ${ }^{36}$ The Court explained that the weighing of rights was not a balancing act with best interests of the child always in the winning corner. Deputy Chief Justice Langa (as he then was) explained the Court's rationale as follows:

33 Fitzpatrick 2000 (3) SA 422 (CC) para 17.

34 De Reuck v Director of Public Prosecutions 2004 (1) SA 406 (CC), hereafter De Reuck.

35 De Reuck v Director of Public Prosecutions (Witwatersrand Local Division, and Others 2003 (3) SA 389 (W); 2002 (12) BCLR 1285 (W).

36 The South African Constitutional approach to deciding whether law or conduct violates rights is to first decide which rights are limited by the impugned provision or conduct, and then move on to the second stage of the analysis, which is to determine whether the limitation of the right is reasonable and justifiable. 
"In the High Court judgment, the view is expressed that persons who possess materials that create a reasonable risk of harm to children forfeit the protection of the freedom of expression and privacy rights altogether, and that section 28(2) of the Constitution "trumps" other provisions of the Bill of Rights. I do not agree. This would be alien to the approach adopted by this Court that constitutional rights are mutually interrelated and interdependent and form a single constitutional value system. This Court has held that section 28(2), like the other rights enshrined in the Bill of Rights, is subject to limitations that are reasonable and justifiable in compliance with section 36." 37

The Court thus found that the law did limit De Reuck's right to freedom of expression, but that this limitation was reasonable and justifiable given the fact that the possession of child pornography "strikes at" the dignity of children, it is harmful to children who are used in its production and because it creates an attitude that views children as sexual objects, and can be used in the grooming of children to engage in sexual activities. ${ }^{38}$ The Court noted that children merit special protection by the state, and referred in this regard to section 28(1)(d) of the Constitution, children's right to be protected from maltreatment, neglect, abuse or degradation In this case the Court consciously decided not to deal with best interests, explained its reasoning in this regard, and considered children's rights to dignity and protection from abuse as weighting factors in the limitations analysis of the right to freedom of expression. The De Reuck case therefore strongly fulfils the requirement that the actual right that is breached or at risk is to be preferred, instead. I recollect that the children's rights sector were somewhat disappointed with this decision at the time, but the approach has stood the test of time, and within the current analysis, one can see the wisdom of the approach.

The Court's interpretation of best interests not being "a trump" came up for consideration again in $S \mathcal{V} M$ (Centre for Child Law as Amicus Curiae). ${ }^{39}$ This case is recognised as a landmark case, ${ }^{40}$ not so much because of its subject matter (the rights of children of caregivers facing imprisonment to have their best interests considered by the sentencing court), but because it was in this case that the Constitutional Court comprehensively set out its approach to best interests. Sachs J pointed out that the very expansiveness of the paramountcy principle appears to "promise everything but deliver little in particular". ${ }^{41}$ The best interests concept is indeterminate, resulting in various interpretations. Sachs J went on to say that it is precisely the contextual nature and inherent flexibility of section 28 that constitutes the source of its strength. The determination of best interests will depend on the circumstances of each case, and this is not a weakness, but a strength. A truly child-centred approach requires an in-depth consideration of the needs and rights of

37 De Reuck 2004 (1) SA 406 (CC) para 55.

38 De Reuck 2004 (1) SA 406 (CC) para 65

392008 (3) SA 232 (CC) (hereafter $S v M$ ).

40 Tobin (2009) 33(2) Melbourne University Law Review 579.

41 Para 23. 
the particular child in the "precise real-life situation" he or she is in. To apply a pre-determined formula for the sake of certainty, irrespective of the circumstances, would in fact be contrary to the best interests of the child. $^{42}$

$S \mathcal{V} M$ is the most quoted of all South African child law cases. ${ }^{43}$ Partly because it was the first case in which the court comprehensively expressed its approach to best interests. Another reason for its popularity relates perhaps to the language and "poetry" it includes. Here is an example:

"No constitutional injunction can in and of itself isolate children from the shocks and perils of harsh family and neighbourhood environments. What the law can do is create conditions to protect children from abuse and maximise opportunities for them to lead productive and happy lives. Thus, even if the State cannot itself repair disrupted family life, it can create positive conditions for repair to take place, and diligently seek wherever possible to avoid conduct of its agencies which may have the effect of placing children in peril." 44

The process of weighing up the best interests of the child received detailed attention in $S \vee M$, building on the previous jurisprudence. ${ }^{45}$ Sachs J also attempted to describe what he called "an operational thrust for the paramountcy principle”. $S v M$ went further than any previous judgment in explaining paramountcy, though it still defined the principle more by stating what it is not, rather than what it is. ${ }^{46}$ It is not an "overbearing and unrealistic trump", and it cannot be interpreted "to mean that the direct or indirect impact of a measure or action on children must in all cases oust or override all other considerations." 47 Sachs J concluded that "the fact that the best interests of the child are paramount does not mean that they are absolute." 48

42 This idea was first articulated in Minister for Welfare and Population Development $v$ Fitzpatrick and Others (CCT08/00) [2000] ZACC 6; 2000 (7) BCLR 713; 2000 (3) SA 422 (CC), and the Court has re-stated this position subsequent to $S \vee M$ in the judgment of $A D$ and Another $v D W$ and Others (CCT48/07) [2007] ZACC 27; 2008 (3) SA 183 (CC); 2008 (4) BCLR 359 (CC) para 55, and in Centre for Child Law v Minister of Justice and Constitutional Development and Others (CCT98/08) [2009] ZACC 18; 2009 (2) SACR 477(CC); 2009(6)SA 632 (CC); 2009 (11) BCLR 1105(CC).

43 Skelton and Courtenay conducted a case law data base search which found this to be the case, the results were reported in A Skelton and M Courtenay "The impact of children's rights on criminal justice: Recent cases" (2012) 25(1) South African Journal of Criminal Justice 180-193.

44 Para 20.

45 Minister for Welfare and Population Development $v$ Fitzpatrick and Others (CCT08/00)[2000]ZACC 6; 2000(7)BCLR 713; 2000 (3)SA 422 (CC) De Reuck $\checkmark$ Director of Public Prosecutions (Witwatersrand Local Division), and Others 2003 (3) SA 389 (W); 2002 (12) BCLR 1285 (W).

46 Skelton "Severing the umbilical chord: A subtle jurisprudential shift regarding children and their primary caregivers" 2008 (1) CCR 351.

47 S V M 2008 (3) SA 232 (CC) para 25.

48 S v M 2008 (3) SA 232 (CC) para 26. 
The judgment concluded that sentencing officers should pay appropriate attention to the best interests children of a primary caregiver and take reasonable steps to minimise damage.

"The paramountcy principle, read with the right to family care, requires that the interests of children who stand to be affected receive due consideration. It does not necessitate overriding all other considerations. Rather, it calls for appropriate weight to be given in each case to a consideration to which the law attaches the highest value, namely the interests of children who may be concerned." 49

This approach focuses on the procedural application of best interests the Court essentially said that from that moment on, courts were required to consider children's best interests as a discrete issue, when sentencing a primary caregiver.

Although $S v M$ related to a criminal matter of a mother, the issue that had to be decided related to whether separation of the primary caregiver from her children by the state would be a violation of the children's rights, if their best interests were not considered at the time of sentencing. The court decided that it would. $S v M$ presents an example of best interests being applied in the situation that relates to parental care, a fairly familiar terrain for the application of best interests, albeit that the State was the initiator of the separation, through sentencing.

Criminal justice is an area in which our courts had not, in the preconstitutional era, been accustomed to applying best interests, although the courts had always viewed youthfulness as a mitigating factor. The two cases that I have chosen to examine in more detail later in this article, about which I have concerns regarding the application of best interests, relate to criminal law. However, they were not the first criminal justice cases. The Constitution ushered in a new era for child justice, and as already demonstrated, the case of $S v$ Williams was one of the earliest cases of the Constitutional Court. Another high point was the case of Centre for Child Law $v$ Minister of Justice. ${ }^{50}$ The case was a constitutional challenge to minimum sentences, linked to certain categories of crime, which applied to 16 and 17 year olds in the same way as it did to adults.

To some extent the Constitutional Court restated what the South African courts already instinctively knew about child offenders, but this time explained it within a constitutional and international child rights framing. This paragraph penned by Cameron J, for the majority, reflects the approach:

"We distinguish them because we recognise that children's crimes may stem from immature judgment, from as yet unformed character, from youthful vulnerability to error, to impulse, and to influence. We recognise that exacting

$49 S v M 2008$ (3) SA 232 (CC) para 42.

50 Centre for Child Law v Minister of Justice and Constitutional Development and Others (CCT98/08) [2009] ZACC 18;2009 (2) SACR 477 (CC); 2009 (6) SA 632 (CC); 2009(11) BCLR 1105 (CC). 
full moral accountability for a misdeed might be too harsh because they are not yet adults. Hence we afford children some leeway of hope and possibility."

Although the judgment rests mainly on a finding that the provision breached section 28(1)(g), namely "detention as a measure of last resort and for the shortest period of time", the court also based part of its decision on best interests.

One interesting aspect was that the minimum sentencing regime used minimum sentences as the starting point, but allowed the courts some discretion to depart where substantial and compelling circumstances were found to exist. This, the court said, went against best interests which must be determined on an individual basis ${ }^{51}$ - and the court cited the $S \mathcal{V} M$ judgment in this regard - that there should be no predetermined formula when deciding children's best interests, which was very relevant in the context of a statutory minimum sentence that automatically applied to everyone in the same measure. ${ }^{52}$ This is an example of the Court applying best interests to fill in a normative gap. Individualisation in sentencing is not included in the Constitution. The court links individualisation to best interests, through the idea that one can only arrive at the correct decision for a child, if you look at the specific facts and circumstances. It probably did so because there was no other obvious right in the Bill of Rights that was infringed by the "one size fits all" approach of minimum sentences, and in my view this was a permissible application, particularly as this was in addition to finding a clear rights violation in respect of the detention as a measure of last resort principle.

In Centre for Child Law v Minister of Justice Cameron J made the point that the constitutional injunction that a "child's best interests are of paramount importance in every matter concerning the child" does not entirely preclude sending child offenders to jail, though this must always be done as a measure of last resort.

"The constitutional injunction that '[a] child's best interests are of paramount importance in every matter concerning the child' does not preclude sending child offenders to jail. It means that the child's interests are 'more important than anything else', but not that everything else is unimportant: the entire

51 For a more detailed discussion of this case and the principle of individuality, see Skelton "Child justice in South Africa: Application of international instruments in the Constitutional Court" 26(3) 2018 International Journal on Children's Rights 391.

52 S v M (Centre for Child Law as Amicus Curiae) 2008 (3) SA 232 (CC) at para 24: "A truly principled child-centred approach requires a close and individualised examination of the precise real-life situation of the particular child involved. To apply a predetermined formula for the sake of certainty, irrespective of the circumstances, would in fact be contrary to the best interests of the child concerned." The idea was first articulated in Minister of Welfare and Population Development v Fitzpatrick 2000 (3) SA 422 (CC) para 18, and the court has restated this position subsequent to $S v M$ in the judgment of $A D v D W 2008$ (3) SA 183 (CC) para 55. 
spectrum of considerations relating to the child offender, the offence and the interests of society may require incarceration as the last resort of punishment."

In my view, the Court's use of both the "last resort and shortest appropriate period of time provision in section 28(1)(g)", and the "best interests provision of section 28(2)" was well balanced. The fact that the minimum sentences were a "first resort" and were very long in duration meant that the impugned provision in the law that made them applicable to 16 and 17 year olds was a clear violation of section $28(1)(\mathrm{g})$, and the judgment is unequivocal about this. The Court also wanted to stress the importance of individualised treatment and greater prospects of rehabilitation for young offenders, but this was not neatly expressed within section 28(1)(g) or any other provision in the Bill of Rights, so the court relied on section 28(2), and the right to have one's best interests determined in all matters, to provide constitutional support for the idea of an individualised approach. In doing so, the Court provided additional support for its finding that the impugned provision was unconstitutional.

Another case where the Court did something similar was Teddy Bear Clinic for Abused Children $v$ Minister of Justice and Constitutional Development. ${ }^{53}$ The case concerned the constitutionality of sections in the Criminal Law (Sexual Offences and Related Matters) Amendment $\mathrm{Act}^{54}$ which criminalised consensual sexual conduct between adolescents. The Court found the impugned provisions were unconstitutional, as they breached the rights to dignity, privacy, and best interests. The court examined adolescents' right to privacy and dignity, finding that these rights are intertwined, and that the "inner sanctum" of personhood is protected from interference by the State, including a person's family life, sexual preferences and home environment. ${ }^{55}$

One of many interesting aspects of this case was that counsel for the Minister of Justice argued that best interests could not be applied in a generalised way - relying on the Constitutional Court's previous jurisprudence that best interests must be determined with a real-life context and that a pre-determined formula would not suffice. The Court gave this argument short shrift:

"During oral argument counsel for the respondent did not pursue this line of attack with any vigour, and rightly so, for it is at odds with the general principle that section 28(2) exists to protect the interests of children, with common sense and with the jurisprudence of this Court." 56

It is interesting to note the Court's view that section 28(2) "exists to protect the interests of children". This idea seems to have led to an

53 Teddy Bear Clinic for Abused Children and Another $v$ Minister of Justice and Correctional Services and Another 2014 (2) SA 168 (CC), hereafter Teddy Bear Clinic.

54 Act 32 of 2007.

55 Teddy Bear Clinic 2014 (2) SA 168 (CC) para [59].

56 Per Khampepe J, Teddy Bear Clinic para 67. 
interpretation by the court that infringements of rights that are child specific or which affect children disproportionately, engage section 28(2). This approach can be seen in some of the judgments under discussion in this article, where the court applies section 28(2) as a support to show that the infringement of a specified right is particularly acute because it is a child's right that is affected, or because there is no other specific right that is infringed but due to the fact that the victim of the violation is a child, section 28(2) fills that gap. In such cases, had the complainant been an adult, the Court might well not have found a violation. For example, the Court had, prior to the Centre for Child Law $v$ Minister of Justice, already upheld the Constitutionality of minimum sentences for adults. The Teddy Bear Clinic case dealt with what one might call a "status" offence. ${ }^{57}$ Children were being criminalised for consensual sexual activity which, if they were adults, would not have been an offence.

Justice Khampepe, writing for a unanimous court in Teddy Bear Clinic $v$ Minister of Justice first dealt with the way that the law infringed privacy and dignity. She then spelled out various ways in which the impugned provisions breach adolescents' best interests. Firstly, the provisions increased harm and risk to adolescents by making it difficult for adolescents to seek support and assistance, because any person they told that they were engaging in unlawful sex would have to report this to police, which would potentially drive adolescent sexual behaviour "underground". Secondly, the Court was concerned that the provisions caused "a rupture" in family life by breaking down the lines of communication between parent and child. Thirdly, the imposition of criminal liability under the impugned provisions may, at worst, lead to imprisonment, and, at best, lead to diversion procedures - and that any of these experiences would be traumatic. Fourthly, the court found that it is "fundamentally irrational to state that adolescents do not have the capacity to make choices about their sexual activity, yet in the same breath to contend that they have the capacity to be held criminally liable for such choices".

Did the court need to apply best interests for these findings? The first problem, of cutting off sexually active adolescents from support and assistance, does not easily fit within the purview of other rights (although arguably it might also be an infringement of dignity, privacy and health rights). The second problem related to the adolescents' need for guidance, and there does seem to be a logic in linking the impugned provision's interruption of this to best interests - the law, in requiring that all sexual offences be reported, meant that adolescents could not ask for advice relating to their consensual sexual activities because they would disclose a crime in doing so. It is perhaps linked also to children's rights to family care and parental care, which is included in the section

57 United Nations Standard Minimum Rules for the Administration of Juvenile Justice Beijing Rules adopted by General Assembly resolution 40/33 of 29 November 1985 , commentary to para 3. 
28(1)(b) of the Constitution, but it goes beyond that as adolescents may prefer to seek guidance in sexual matters from other people beyond their families.

The Court's emphatic statement that children could be traumatised by being at worst, imprisoned and at best, diverted, indicates that the court wanted to stress that because they were children, this would be particularly grave. The Court was clear that the legislature could not have it both ways - they could not tell adolescents they were too immature to make decisions about sex and in the same breath tell them that they were mature enough to face criminal charges for the same actions. Again, this was not a clear breach of any other right, and that is perhaps the reason why the Court clustered it here, under the rubric of best interests.

However, best interests was not the only right that was found to have been breached - overall, the Court provided strong rationale for its findings that the impugned provisions violated the rights to privacy and dignity, and best interests was used to "gather" other aspects that were less clearly linked to a specific right in the Constitution.

\section{Recent cases that may have over-utilised best interests}

So up until this point, the Court generally framed best interests carefully, and retained a focus on the other substantive rights that applied. The Court used best interests as a right in cases where it was the obvious right that was breached, to support the findings of violations of other rights, to weigh on the other side of competing rights during the limitations analysis, to emphasise certain traits or vulnerabilities peculiar to children, or to fill in normative "gaps" where there no other right was directly applicable. The approach of the court was thus compatible with the Cantwell approach of a more constrained and carefully targeted approach to the application of best interests. Two more recent cases, however, show the Court applying best interests either to the exclusion of any other rights or as a alternative to other rights, even though breaches of those rights could, and I would argue should, have been found.

It was in $S v M$ that Sachs $\mathrm{J}$ issued his warning that children's best interests could become so ubiquitous that it would lose it strength. He said that "[i]f the paramountcy principle is spread too thin it risks being transformed from an effective instrument of child protection into an empty rhetorical phrase of weak application, thereby defeating rather than promoting the objective of section $28(2)$ " 58 This article takes that warning as a basis for analysis of the two selected cases showing evidence of this over-utilisation of the best interests. 
The first case is $J v$ National Director of Public Prosecution. ${ }^{59}$ There is so much that I like about this judgment, which declared unconstitutional sections that required the automatic placement of child sex offenders on the National Register for Sex Offenders. The judgment was the "swan song" of Justice Skweyiya, it is imbued with a deep consideration for children's rights, and is beautifully written. J was a 14 year old boy who I would not have chosen as test case material. He had raped three much younger children and threatened a 12 year old with a knife. As luck would have it, it was his case that the reviewing High Court judge decided to use as a platform to review the constitutionality of the law. In the Constitutional Court judgment, Skweyiya J, in a truly inspired move, having briefly dealt with the facts of J's cases, shifted the discussion to a hypothetical offender who he referred to throughout as "she". This magically transforms the way that the reader feels about the young sex offender, the importance of treating her as an individual, believing in her reformability. The judgment is redolent with true and beautiful phrases. In this passage we get a clear idea of how Skweyiya J was thinking about best interests:

"The contemporary foundations of children's rights and the best-interests principle encapsulate the idea that the child is a developing being, capable of change and in need of appropriate nurturing to enable her to determine herself to the fullest extent and to develop her moral compass. This Court has emphasised the developmental impetus of the best-interests principle in securing children's right to 'learn as they grow how they should conduct themselves and make choices in the wide and moral world of adulthood'. In the context of criminal justice, the Child Justice Act affirms the moral malleability or reformability of the child offender." 60

Here the Court appears to be linking best interests to the idea of "evolving capacity". Varadan has pointed out that the Committee of the Rights of the Child's General Comment No. 14 on best interests uses "evolving capacities" as an interpretative principle to maintain balance between protection and autonomy. ${ }^{61}$ The Court does the same in this case, but also captures the essence that moving from birth to adulthood is a process of development, in which children should be guided but also increasingly permitted to make their own choices. Skweyiya J connects this to what he calls "moral malleability or reformability" - a belief that adolescents are going through a period of rapid development and that their formative experiences can affect their future trajectory. This should lean justice towards solutions for young offenders that do not brutalise, stigmatise or isolate them. Another passage from the judgment fleshes out this idea so well that I prefer to quote it rather than paraphrase:

59 (CCT 114/13) [2014] ZACC 13; 2014(2) SACR 1 (CC); 2014 (7) BCLR 764 (CC), hereafter $J v N D P P$.

60 Ibid para 36.

61 Varadan "The principle of evolving capacities under the UN Convention on the Rights of the Child (2019) 27 International Journal of Children's Rights 306-338. 
"Child offenders who have served their sentences will remain tarred with the sanction of exclusion from areas of life and livelihood that may be formative of their personal dignity, family life, and abilities to pursue a living. An important factor in realising the reformative aims of child justice is for child offenders to be afforded an appropriate opportunity to be reintegrated into society. Furthermore, it is undoubted that there is a stigma attached to being listed on the Register even if the Sexual Offences Act closely guards the confidentiality of its contents. Given that a child's moral landscape is still capable of being shaped, the compulsory registration of the child sex offender in all circumstances is an infringement of the best-interests principle."62

What was particularly difficult in this case was that the impugned provision applied generally to all convicted sex offenders. It appeared that the legislature had overlooked the need to consider child offenders differently from adults. The aim of the register is to prevent any person who has committed a sexual offence from being employed in positions that would put them in contact with children. ${ }^{63}$ The court found this was a valuable aim, but then went on to find that the limitation of child offenders' rights occasioned by the automatic placement on the register was neither reasonable nor justifiable. The reasons were firstly because it was based on a flawed idea that all child sex offenders grow up to become adult sex offenders, and secondly because there were less restrictive means to achieve the same purpose.

So what is the problem with the judgment then? It is important to note that Counsel for the applicant had submitted that having one's particulars entered on the Register infringes that offender's rights to dignity, privacy, fair trial and fair labour practices, as well as freedom of trade, occupation and profession. The applicant argued that actually, all offenders' rights were infringed by the impugned provisions. ${ }^{64}$ The amici curiae $^{65}$ argued that the case should be restricted to child sex offenders, because J, whose case it was, was a child, and because there had not been full argument about adult sex offenders.

The Court distilled three principles that related to best interests: First, the court found that the law should generally distinguish between adults and children. It was therefore a problem that the provisions in the law on the Sex Offenders Register treated children and adults alike. Secondly, the court found that the law should allow for an individuated approach to

$62 J v$ NDPP (CCT 114/13) [2014] ZACC 13; 2014(2) SACR 1 (CC); 2014 (7) BCLR 764 (CC) para 44.

63 The provision also prevents them for working with persons with mental disabilities, but for the purposes of this article, I have focused on the aspect of working with children.

64 This was also the approach of the court a quo ( $v \mathcal{V} S$ [2013] ZAWCHC 114; 2013 (2) SACR 599 (WCC). reference is in the CC judgment). Although that case has arisen from the review of J's case and argument was therefore focused on child offenders, the court found, on the basis of audi alterem partem, that the provision was unconstitutional vis-à-vis all convicted sex offenders.

65 Childline, Teddy Bear Clinic and NICRO, represented by the Centre for Child Law. 
child offender. Here the best-interests standard must always be applied flexibly because individual factors will secure the best interests of a particular child. The court pointed out that proportionality was a factor here, too, because in deciding on the correct approach the criminal court would have to weigh all factors, and the rule of automatic placement on the register made this impossible. Thirdly, the court held that children should be given an opportunity to make submissions before a decision to place them on the register is made. The Court stated that "the child or her representatives must be afforded an adequate opportunity to make representations and to be heard at every stage of the process, giving due weight to the age and maturity of the child". 66 The Court went on to point out that this is accommodated under the guiding principles of the Child Justice Act - that "every child should, as far as possible, be given an opportunity to participate in any proceedings ... where decisions affecting him or her might be taken". 67 Here the Court makes underscores the right to participation, adding a footnote ${ }^{68}$ setting out article 12(1) of the CRC (although article 12(2) was more relevant) and quoting an entire passage from General Comment no 12 on the right of the child to be heard. ${ }^{69}$ The court then went on to explain the significant consequences for children of being placed on the register, that they will be impeded from working, once they become adults. They will be stigmatised, and this stigma will follow them into adulthood. Assessing the Court's application of best interests in $J \mathcal{V} N D P P$, it is apparent that there are several aspects that were defensibly included under a best interests rubric. For example, the first principle, that children should be treated differently from adults, is an appropriate issue for application of best interests because it captures the essence, somehow missing or incompletely articulated in the general Constitutional or human rights

66 Para 40 of the judgment.

67 Para 40 of the judgment, referring to s 3(c) of the Child Justice Act, no 75 of 2008

68 Footnote 45 of the judgment, which reads as follows: $C$ and Others $v$ Department of Health and Social Development, Gauteng, and Others [2012] ZACC 1; 2012 (2) SA 208 (CC); 2012 (4) BCLR 329 (CC) at para 27. Section 10 of the Children's Act 38 of 2005 embodies this component of the bestinterests principle in requiring that every "child that is of such an age, maturity and stage of development as to be able to participate in any matter concerning that child has the right to participate in an appropriate way and views expressed by the child must be given due consideration." See also Article 12 of the Convention on the Rights of the Child, November 20, 1989, 1577 UNTS 3; 28 ILM 1456 (1989), which obliges state parties to ensure that a child who is capable of forming his or her own views enjoys the right to express those views in matters affecting the child and that those views be given due weight. See, in this respect, Committee on the Rights of the Child, "General Comment No 12 (2009): The right of the child to be heard" Fifty-first Session, 20 July 2009, CRC/C/GC/12 at paras 1 and 15. At para 57, the Committee affirmed that the right extends "throughout every stage of the process of juvenile justice." See also Committee on the Rights of the Child, "General Comment No 10 (2007): Children's rights in juvenile justice" Forty-fourth Session, 25 April 2007, CRC/C/GC/10 at paras 12 and 43-5.

$69 \mathrm{CRC} / \mathrm{C} / \mathrm{GC} / 12$, par 27 
framework, that the impact of the law will be greater on children than on adults, and that children are more capable of reform and reintegration. The second principle, about the need for individualisation and proportionality is closely allied to the first, and the application of best interests is equally defensible. The courts have applied best interest in relation to these principles previously in Centre for Child Law v Minister of Justice, and in Teddy Bear Clinic v Minister of Justice, as discussed above.

It is in respect of the last principle, that the child should have an opportunity to place his or her views before the court, in which best interests may have been spread a little too thinly. The invocation of a child's right to participation in Court judgments is rare, particularly when bolstered with a reference to the Convention and the relevant General Comment, so I feel a sense of regret to criticise this part of the judgment. However, the Court could have strengthened its position by including in the text of the judgment a clear reliance on the right set out in article $12(2)$ of the Convention - which provides a child "the opportunity to be heard in any judicial and administrative proceedings affecting the child, either directly, or through a representative or an appropriate body, in a manner consistent with the procedural rules of national law". The procedural rules of South African law also embody the fair trial concept of audi alterem partem - hear both sides - and there was written and oral argument about this before the Court. To apply article 12(2) of the CRC, in the absence of a clear right in the Constitution, would have been a more rights based approach.

- The Court did not explain why it decided to hook this last issue into best interests. It appears that the Court decided that it had to find a way to restrict its judgment to affect child sex offenders only, and in order to do so, it used the best interests principle as a basket into which all the other rights infringements could be placed. The rationale, I surmise, was that if the Court did not do this, it would be difficult for to avoid making statements that would provide footholds for adult sex offenders to make claims that the law was unconstitutional with regard to them in the future. Thus, encapsulating everything within a best interests basket isolated the Court's findings from easy generalisation, and limited them to child offenders only. Is this another permissible use of best interests? Although it does link to the idea of children being "different from adults", it is preferable for a Court to link the violation to a right in the Constitution, or failing that a right in the Convention such as article 12(2), and spell out why a restrictive law violates the rights of a child, but is justifiable when applied to an adult. I concede though, that this might require a consideration of factors such as individualisation, proportionality and reformability which are difficult to link to anything but best interests. On consideration, I can certainly see a logic to the Court's approach, and in the context of $J v N D P P$, little harm was done. However, in the final case that I am going to consider, one can see a different effect, which raises some cause for concern. 
Radhuva $v$ Minister of Safety and Security ${ }^{70}$ dealt with a civil claim for damages brought by Michell Radhuva against the police arising from an unlawful arrest and pre-trial detention. The police had been attempting to arrest Michell's mother for disturbing the peace, and 15 year old Michell, trying to prevent the arrest, placed herself between the police officer and the mother. She was arrested for interfering with a police officer in the course of his duties, into the police van along with her mother, and taken to the police station where she was detained for 19 hours. This despite the fact that her father was present at the arrest, and also that he came to the police station and requested that the police release her into his care. The charges were later dropped. Michell launched her claim for damages in the High Court, where she lost because the Court did not accept that her arrest and detention were unlawful, and her appeal to the Supreme Court of Appeal was similarly unsuccessful. She then appealed to the Constitutional Court. Here the Centre for Child Law entered the matter as amicus curiae and argued that Michell's arrest and detention was a breach of section 28(1)(g) of the Constitution, namely that "every child has the right not to be detained except as a measure of last resort, and for the shortest appropriate period". Until this case, the Constitutional Court had not been called upon to interpret that provision in the pre-trial context, though it had done so before in relation to sentencing in Centre for Child Law $v$ Minister of Justice. It was therefore an important opportunity to extend the application of the principle of last resort and shortest appropriate period to all types of detention, including arrest.

The amicus argued that the words "not to be detained" operated from the moment of arrest, and to pre-trial detention, that both should be considered a measure of last resort, but also that official are under a positive obligation to ensure that their actions are based the best interests of the child. The court had no difficulty finding that the police cell detention was a breach of the last resort and shortest period protections in section 28(1)(g) - but declined to find that the arrest breached that right. ${ }^{71}$ Instead, the court invoked best interests - and found that the arrest had been a breach of that right, section 28(2).

The Court found that the evidence in the record of the case revealed a lack of knowledge and appreciation by the police officers of "their constitutional obligation when arresting a child to consider her best interests as demanded by section 28(2)."72 The police should have been cognisant that she was no danger to them; that they could have handled or subdued her with ease; that she did not try to run away; that she was not causing any physical harm to them; that she was at or near her

70 (CCT 151/15) [2016] ZACC.

71 The Court did, however, state (at para 58) that "arrest of a child should be resorted to when the fact are such that there is no other less invasive way of securing the attendance of such a child before a court" - which sounds very similar to a last resort principle, but the Court declined to find a breach of section 28(1)(g).

72 Para X. 
parental home and, importantly; that her father was present. The Court found that there was no doubt that the approach they applied to arresting Michell was a breach of her section 28(2) rights. If the police officers had properly considered best interest, the Court opined, there would have been no reason to arrest her. They could have issued a summons or a written notice to appear, and could have left her in the custody of her father with instruction to bring her to court. The Court ultimately found that as the arrest was a violation of section 28(2), it was unlawful. ${ }^{73}$

For Michell, the fact that the arrest was declared unlawful was sufficient, so that her civil claim could succeed. For the development of child law, however, it was really important how the court arrived at this conclusion. In my view, the court erred in not finding that the arrest was a breach of section 28(1)(g). Writing elsewhere, ${ }^{74}$ I have commented on several positive aspects of the Radhuva case, so as with $J v N D P P$, I am loath to criticize it without also mentioning some of its positive features. One of these is that it viewed the issue of arrest and detention within the context of South Africa's violent and repressive history, in which arrest and detention was used a tool by the Apartheid state. Bosielo J, writing for a unanimous Court, found that "children should be treated as children - with care, compassion, empathy and understanding of their vulnerability and inherent frailties. Even when they are in conflict with the law, we should not permit the hand of the law to fall hard on them like a sledgehammer lest we destroy them". 75 The judgment hammered home the dangers of detention of children, an atmosphere "not conducive to their normal growth, healthy psycho-emotional development and nurturing as children". 76

The judgment is, however, weak on its recognition of international law. ${ }^{77}$ The Court did not accept arguments before it that Article 37(b) of the Convention on the Rights of the Child provides that the arrest, detention or imprisonment of a child shall be in conformity with the law and shall be used only as a measure of last resort and for the shortest appropriate period of time. However, the wording of section 28(1)(g) is less expansive. It says "every child has the right not to be detained except as a measure of last resort, in which case, ..., the child may be detained only for the shortest appropriate period of time". This was thus a perfect opportunity to get to the court to fill in the normative gap through

73 The Court did not do as the amicus urged it to, however. It did not find that this was a separate factor that had to be considered, but something similar, though at once vaguer and more all encompassing: when police considered all the other required factors for a lawful arrest, they would additionally have to consider, as a paramount consideration, the best interests of the child.

74 A Skelton "A hiding to somewhere" in W O'Brien and C Foussard Violence against children in the criminal justice system (2019) 145-163.

75 Radhuva para 59.

76 Radhuva para 68.

77 Skelton "Child justice in South Africa: Application of international instruments in the Constitutional Court" 26(3) 2018 International Journal on Children's Rights 391. 
interpreting it with reference to Article $37(\mathrm{~b})$ of the Convention, and this was fully argued by the applicant and the amicus curiae. ${ }^{78}$ Instead it filled the gap with section 28(2) of the Constitution. This, in my view is an incorrect application of the best interest principle.

It is not clear why the Court decided to go the route that it did. Speculating, I note that in addition to being mentioned in section 28(1)(g), the word "detained" is used in section 35 of the Constitution which is the section that protects all offenders' rights. Perhaps the court was concerned that if it defined detention as including arrest for children, it would open the door to a similar interpretation for adults. To avoid this, the Court used the best interests right instead. If so, then it follows the pattern of the Court's approach in $J \mathcal{V} N D P P$, but in this case the result is more egregious because it created a way out for the court to avoid interpreting section 28(1)(g) in line with more directly applicable in international human rights law. Again the court could have broadened the interpretation of sections 28(1)(g) for children to include arrest, and justify why this might not be the case for adults, after all section 28(1)(g) does apply only to children, there is no equivalent right in the Constitution for adults.

Couzens has subjected the South African jurisprudence on best interests to a wide- ranging critique and in a recent article she has analysed $J v N D P P$ and Radhuva. ${ }^{79}$ She points out that in Radhuva it is not clear if the Court is invoking section 28(2) as self standing right, or as an interpretive principle, as the Court does not offer sufficient substantiation. She is of the view that the case advances a "child-sensitive approach" in a matter which, she says, was not covered by another more specific constitutional right. In my view, the Court had another option open to it. There was a normative gap, in that section 28(1)(g) referred only to detention and not expressly to arrest. The South African Constitution requires that when considering a right in the Bill of Rights, the Court must consider international law, and must favour an interpretation that accords with international law. ${ }^{80}$ If it had interpreted section 28(1)(g) in the light of article 37(b) of the CRC, a more substantive, rights based outcome would have been achieved. Couzens views these two cases as examples of a positive application of section 28(2) as a having independent normative value, to fill in gaps where there is no specific provision that is directly applicable. ${ }^{81}$ She raises the

78 The arguments of the parties and the applicants are available at https:// www.concourt.org.za.

79 Couzens (2019) Constitutional Court Review (Forthcoming). See also earlier articles: M Couzens "The Constitutional Court consolidates its child-focused jurisprudence: The case of $C v$ Department of Health and Social Development, Gauteng" 2013 (130) South African Law Journal 672; M Couzens "Le Roux and Others $v$ Dey (Freedom of Expression Institute and Restorative Justice Centre as Amici Curiae) and Children's Rights Approaches to Judging" 2018(21) Potchefstroom Electronic Law Journal.

80 Section 39 (b) and 233 of the Constitution.

81 Couzens (2019) Constitutional Court Review (Forthcoming). 
question as to whether the approach of the Court in these two cases is the beginning of "a subsidiarity approach to the independent application of 28(2)". 82 In other words, whether the Court from now on will only apply section 28(2) as a self-standing right when more specific constitutional rights are not available to it. That remains to be seen. However, the Court did not clearly articulate that it was filling a normative gap in either of the cases, and it is not clear what theoretical approach to application of best interests the Court is applying. Regrettably, the Court's best interests jurisprudence has become vaguer in recent judgments.

\section{Conclusion}

The Convention ushered in a new era in which children are rights bearers. Best interests was included, but it was never meant to supplant rights. The South African Constitutional Court's early jurisprudence showed a careful approach to the application of best interests. Even though counsel before it argued best interests in cases such as $S v$ Williams and Christian Education, the court declined to consider it or paid minimal attention to it, preferring to focus on the direct rights violations regarding "cruel, inhuman or degrading treatment", "dignity" and "protection from violence". Interestingly, all of these rights are found not in the section of the Constitution that deals with children's rights, but in other sections of the Bill of Rights that deals with all human rights. So the court got off to a good start. The case of Fitzpatrick was important because it articulated that best interests was both a self-standing right and an interpretive principle. De Reuck was the wake-up call that best interests was not a trump, that there was no hierarchy of rights, but that best interests would still weigh heavily as a right when measured against other rights. $S \mathcal{V} M$ continued in that vein, and gave more guidance on what is meant by paramountcy. It also made it clear that from that point on, judicial officers were required to separately weigh best interests when sentencing a primary caregiver.

In Centre for Child Law v Minister of Justice the main violation was to section 28(1)(g) (measure of last resort and shortest appropriate period of time) but the court also used best interests to draw in violations relating to the legislature's denial, through minimum sentencing, of the need to consider each child individually, and to apply proportionality in sentencing. This was done in a balanced way, and demonstrated effectively how best interests can, after a rights violation is found on one ground, be used to add detailed issues that are not included in any other normative standards. Teddy Bear Clinic $v$ Minister of Justice shows much the same approach, where the Court found clear rights violations of privacy and dignity, and additionally captured the essence of children being more harshly affected than adults would be, and the concern that 
making sexual interaction a crime would prevent children from being guided by their parents, under the rubric of best interests.

The case of $J \mathcal{V}$ NDPP marked a shift in the Court's approach, by placing a number of identifiable rights violations into a best interests basket. The Court might have been wiser to follow the approach in Centre for Child Law and Teddy Bear Clinic, namely to pronounce on a clear rights violation, either in the Constitution or the Convention, and then use best interests to fill in any normative gaps. Radhuva is more problematic and here the outcome is more disappointing, as an opportunity for norm clarification using the Convention was missed, and was supplanted by the requirement for a best interests determination by police officers at the point of arrest. Stalford and Hollingsworth have pointed out that while best interests offers "a neat shorthand for promoting the best outcomes for children" its ubiquity papers over the cracks of complexity. ${ }^{83}$ The South African Constitutional Court has built a powerful jurisprudence on children's best interests, but it is important that ongoing and careful attention is paid to ensuring that children are recognized as rights bearers of all the rights in the Constitution. Without losing its commitment to best interests, and while continuing to provide the kinds of ringing statements that make its child rights jurisprudence bold and memorable, the court must guard against romanticism, the Court must guard against simplification and must avoid papering over the cracks of complexity.

83 Stalford and Hollingsworth "Judging children's right: Tendencies, tensions, constraints and opportunities" in H Stalford, K Hollingsworth and S Gilmore (eds) Rewriting children's rights judgments: From academic vision to new practice 64. 